\title{
Assessment of Drinking Water Quality of Different Areas in Tehsil Isa Khel, Mianwali, Punjab, Pakistan
}

\author{
Hizbullah Khan ${ }^{* 1}$, Muhammad Najeeb $\operatorname{Khan}^{1}$, Muhammad Sirajuddin ${ }^{1}$, \\ Syed Muhammad Salman ${ }^{2}$ and Muhammad Bilal ${ }^{3}$ \\ ${ }^{*}$ Department of Chemistry, University of Science and Technology Bannu, 28100, Pakistan. \\ ${ }^{2}$ Department of Chemistry, Islamia College, Peshawar, Pakistan. \\ ${ }^{3}$ Department of Chemistry, Kohat University of Science and Technology, Kohat, Pakistan. \\ *Corresponding Author Email: hizbmarwat@yahoo.com \\ Received 19 October 2020, Revised 06 December 2021, Accepted 10 December 2021
}

\begin{abstract}
Water samples were collected from 43 sites of Tehsil Isa Khel areas in order to determine the physicochemical parameters such as $\mathrm{pH}$, electrical conductivity, turbidity, total hardness, calcium hardness, magnesium hardness, M. alkalinity, chloride ion $\left(\mathrm{Cl}^{-}\right)$, and fluoride ion (F-) concentration. The obtained results show that in Tehsil Isa Khel, only in Kala Bagh city, Kala Bagh water scheme (w/s), Tola Bangi Khel w/s, Kot Chandna, Awan Wala, Gidran Wala, and Cheena Pora water is drinkable. Overall, electrical conductivity, hardness, total alkalinity, chloride, fluoride levels in the water of Tehsil Isa Khel are very high and not fit for drinking, washing, and industrial purpose. The ultimate result of this study is helpful to address the leading cause of public health problems related to the deteriorated quality of drinking water, and an integrated approach is therefore required to provide safe drinking water to people in Tehsil Isa Khel.
\end{abstract}

Keywords: Drinking water, Tehsil Esa Khel, Fluoride level, Total alkalinity, Hardness

\section{Introduction}

Water is the most important abiotic component of the environment. Water is essential for the life of all living organisms. A large portion of total water, approximately $97 \%$ is in oceans, not fit for drinking purposes, and fresh water is $3 \%$, out of which $2.97 \%$ is in ice caps and glaciers. Only a tiny portion of $0.03 \%$ is obtainable as ground and surface water for human use [1]. The good health of people requires harmless drinking [2]. In addition, it is not possible to imagine a clean environment without water.

Water quality determines how much water is good. Water that is suitable for cooking and drinking purpose is potable water. The potability of water considers its effects on the health of its consumers [3]. The health of people depends on safe drinking water, so it is internationally accepted that safe drinking water is a human right [2]. Water that contains different heavy metals such as $\mathrm{Hg}, \mathrm{Cr}, \mathrm{Cd}, \mathrm{Zn}, \mathrm{Ni}, \mathrm{Pb}, \mathrm{Co}, \mathrm{Cl}$, F, etc., has adverse effects on the health of humans either through toxicity due to excessive intake or deficiency [4]. Excessive ingestion of heavy metals including $\mathrm{Hg}, \mathrm{Cd}, \mathrm{Cr}, \mathrm{Co}, \mathrm{Pb}$, $\mathrm{Zn}$, and Ni cause a carcinogenic effect on the health of humans [5]. The scarcity of fresh water increases globally due to overpopulation [6]. 
Today, approximately one billion people in the world, most living in developing countries, are not drinking safe water [7]. According to World Health Organization (WHO), around 94 percent of the global diarrheal diseases and 10 percent of the total diseases are due to poor hygienic drinking water [8]. The most important factor affecting drinking water quality is water distribution systems that deliver water to consumers [9]. If any town's domestic water supply system has low standard water (bacteriological and physicochemical), people must stop drinking water from this unsafe source [10]. This is a challenge in achieving the Millennium Development Goals (MDGs) of improving public health in the rural areas of developing countries [11]. There are several pathways of transmission of water-borne diseases. These include contamination of drinking water by animal or human faeces. Millions of people are using contaminated drinking water. This is due to a lack of proper management of agricultural run-off water and industrial wastewater, which gives rise to pollutants that can have serious health impacts.

Many researchers have worked on drinking water and human rights [12]. The population of the world is increasing rapidly, and this continuous increase in population results in scarcity of fresh water for domestic, agriculture, and industrial use in the world [13]. There are many sources of water contamination that make it unsuitable for drinking purposes. Generally, bacterial contamination is widespread [14]. Contaminated water, food, and air increase the risk of exposure to toxic metals [15]. Bacteria spores are discovered in water from the air, sewage, organic waste, dead plants, and animals. At times, almost all microorganisms can be found in water, but bacteria are the most common [16]. Ground water is used for drinking purposes in most areas of Pakistan. In some areas, impurities level in drinking waters is above the recommended level by WHO [17]. Agricultural and industrial waste disposal increases water toxicity. The toxic metals are entered into the water through the hydrological cycle $[15,18]$. A strong positive correlation has been found between the total bacterial count and physicochemical parameters in the domestic water sources of Samaru community, Zaria, northcentral Nigeria [19]. The release of heavy metal wastes into receiving waters can cause various physical, chemical, and biological problems, including reduced energy levels, DNA damage, and gene expression changes [20].

This research attempts to assess the drinking water quality from the main existing drinking water system of Tehsil Isa Khel in terms of water quality and various physicochemical parameters. The ultimate result of this study is to address the leading cause of public health problems due to deteriorated quality of drinking water and to point out the ways to produce safe water for the population of the Tehsil.

\section{Material and Methods Chemicals and Reagents}

Demineralized water (DM water), silver nitrate, EDTA sulfuric acid, zirconyl chloride, erichrome cynanine, potassium dichromate, erichrome black T, Tashiro or bromo cresol green, potassium hydroxide $30 \%$, ammonium hydroxide + ammonium chloride (mixture) were used. All the reagents were of analytical grade, purchased from Merck, Kenilworth, NJ, USA and used without further purification.

\section{Survey and Sampling}

The study area was surveyed during 2017. The work plan was scheduled before the start of field and lab work. General information about drinking water, water-borne diseases and public health status in study areas 
were collected. Frequent trips were conducted to the study area. Water samples were carefully collected from two different sources: a borehole and a water supply scheme. Samples were collected from all designated sampling points, as shown in Fig. 1. The samples were collected from the tube well supply, and the bore size of the tube wells was eight inches, while the bore size of the water supply was fourteen inches (Table 1). Samples were collected into a $500 \mathrm{~mL}$ sterilized bottles. Each sample was labelled on the spot with sample ID, area name and depth of water level. These samples were transported to the laboratory for analysis.

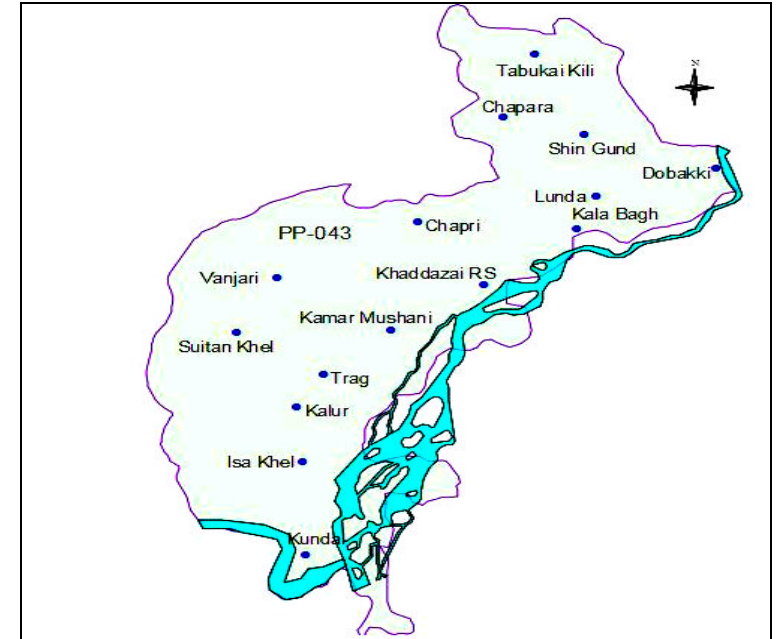

Figure 1. Map of study area of Tehsil Isa Khel

Table 1. Sampling point areas.

\begin{tabular}{|c|c|c|c|c|c|}
\hline Sample ID & Sampling area name & Depth (Feet) & Sample ID & Sampling area name & Depth (Feet) \\
\hline S.01 & Isa Khel city & 70 & S.23 & Murghan Wala & 400 \\
\hline S.02 & Isa Khel w/s & 230 & S.24 & Mussa Khel & 200 \\
\hline S.03 & Sheikh Abad & 100 & S.25 & Allami Khel & 180 \\
\hline S.04 & Khaglan Wala & 550 & S.26 & Sarmat Khel & 140 \\
\hline S.05 & Gidran Wala & 586 & S.27 & Dilla Mir Wala & 185 \\
\hline S.06 & Kaluwan Wala & 125 & S.28 & Ghagran Wala & 150 \\
\hline S.07 & Cheena Pora & 40 & S.29 & Gulshan colony & 120 \\
\hline S.08 & Miana Wala & 350 & S.30 & Shaadi Khel & 110 \\
\hline S.09 & Kalur & 230 & S.31 & Kamar Mashani & 120 \\
\hline S.10 & Awan Wala & 450 & S.32 & Allah Khel & 130 \\
\hline S.11 & Trag w/s & 220 & S.33 & Burzi & 85 \\
\hline S.12 & Mittah Khattak & 575 & S.34 & Khuddazai & 103 \\
\hline S.13 & Sultan Khel, Moqeem colony & 320 & S.35 & Manda Khel & 100 \\
\hline S.14 & Sultan Khelmadrissa & 635 & S.36 & Jalalpur & 80 \\
\hline S.15 & Makarwal w/s & 450 & S.37 & Kot Chandna & 70 \\
\hline S.16 & Dera Malla Khel & 430 & S.38 & Tola Bangi Khel & 70 \\
\hline S.17 & Gardari & 330 & S.39 & Tola Bangi Khel w/s & 80 \\
\hline S. 18 & Vanjari & 490 & S. 40 & Tabisar & 60 \\
\hline S.19 & Chapri & 432 & S. 41 & Kala Bagh Lariadda & 75 \\
\hline S. 20 & Odhey Wala & 300 & S. 42 & Kala Bagh w/s & 70 \\
\hline S.21 & Kaseeri Wala & 480 & S.43 & Kala Bagh city & 80 \\
\hline S.22 & Malla Khel & 200 & & & \\
\hline
\end{tabular}


Determination of Physicochemical Parameters

The physicochemical water quality parameters analyzed in the laboratory were color, odor, taste, $\mathrm{pH}$, electrical conductivity (EC), total dissolved solids (TDS), turbidity, total hardness, calcium hardness, magnesium hardness, M. alkalinity, chloride and fluoride.

\section{pH}

The $\mathrm{pH}$ values of samples were determined using a JENWAY $3305 \mathrm{pH}$ metre. The $\mathrm{pH}$ sensor is calibrated by comparing the $\mathrm{pH}$ sensor output voltage to the $\mathrm{pH}$ meter measurement results [22]. The water sample was rapidly shaken before being placed in a conical flask. The $\mathrm{pH}$ metre probe was cleaned in distilled water before being inserted into the sample. The $\mathrm{pH}$ was measured once it had stabilized.

\section{Total dissolved solids (TDS)}

The calibrated ADWA, AD3000 EC/TDS, and temperature metres were used to compute TDS. The sample was stirred and transferred into a $100 \mathrm{~mL}$ graduated cylinder, after which the probe was rinsed with distilled water and immersed in the sample water. The readings were taken once the device had been stabilized. The dissolved ions concentration is usually measured as total dissolved solids. Water quality metrics such as conductivity or EC and TDS are often utilised, especially in coastal areas. These two values are salinity markers, making them an excellent tool for studying seawater intrusion [23].

\section{Electrical conductivity (EC)}

Water samples were tested for conductivity using a calibrated ADWA, AD3000 EC/TDS, and temperature metres. The sample was thoroughly agitated before being poured into a conical flask. The conductivity metre probe was washed and dipped in distilled water before being plunged into the sample. The readings were recorded once they had stabilized. The EC of each buffer solution is different (typically $1.41 \mathrm{mS} /$ $\mathrm{cm})$. Set the EC metre to that precise EC after immersing the probe in the buffer solution by turning the knob on the EC metre. This can be used to calibrate an EC metre $[23,24]$.

\section{Turbidity}

The standard method of USEPA Method 180.1 was used to measure the turbidity of the analyzed samples [25]. Turbidity was measured using a $\mathrm{HACH}$ turbidity metre. The accuracy of the turbidity metre was tested. After being cleaned with distilled water, the cuvette was filled with a sample. The cuvette was sealed with a cap and put into the instrument light cabinet. A turbidity reading was collected once the water had stabilized.

\section{Total Hardness}

Complexometric titration of calcium and magnesium with an aqueous solution of the disodium salt of EDTA at pH 10 is used to determine the overall hardness of water [26]. A few drops of ammonia as a buffer solution were added to increase the $\mathrm{pH}$ of sample up to 10. Two drops of indicator erichrome black $\mathrm{T}$ were added. The red color was developed. Then contents of the conical flask were titrated against a standard EDTA solution $(0.01 \mathrm{M})$ until color of contents in the flask changed from wine-red to blue at the endpoint. Titration was repeated three times and the value of the average titer was recorded.

Totalhardness $\left(\mathrm{mg} / \mathrm{LC}_{\mathrm{a}} \mathrm{CO}_{3}\right)=\frac{(\mathrm{M})(\mathrm{V})(100,080)}{\mathrm{S}}$ 
Where $\mathrm{M}=$ molarity of EDTA, $\mathrm{V}=$ volume of EDTA $(\mathrm{mL})$, and $\mathrm{S}=$ sample volume $(\mathrm{mL})$ [27].

\section{Calcium Hardness}

The mineral ions calcium and magnesium form compounds with ethylenediaminetetraacetate (EDTA). A complexometric titration can be used to determine the quantity of these minerals in a sample using this procedure [28]. $50 \mathrm{~mL}$ of the sample was taken in a $250 \mathrm{~mL}$ conical flask and added $4 \mathrm{~mL}$ aqueous $\mathrm{KOH}$. Then 0.5 $\mathrm{mL}$ of hydroxylamine hydrochloride $\left(\mathrm{NH}_{2} \mathrm{OH}\right)$ and a few drops of indicator were added. Then contents in the conical flask were titrated against $0.01 \mathrm{M}$ EDTA until the end point indicated by bluish coloration. Titration was repeated three times. Since EDTA forms a 1:1 complex with $\mathrm{Ca}^{2+}$ under these experimental conditions, the millimoles of calcium present can be found by calculating the number of millimoles of EDTA consumed during the titration using the equation:

Millimoles of EDTA $=$ mL EDTA $X$ molarity EDTA

\section{Magnesium Hardness}

The magnesium hardness of samples was calculated from the difference of total hardness and calcium hardness obtained by the titration method. Total hardness and calcium hardness were determined by EDTA titrimetric method. Magnesium hardness was calculated from the total hardness and calcium hardness differences and expressed in the same units.

Magnesium hardness $=$ (Total hardness Calcium hardness) x 0.243

Where, $0.243=$ Atomic weight of magnesium / Molecular weight of $\mathrm{CaCO}_{3}$.

\section{Alkalinity}

$50 \mathrm{~mL}$ of sample was taken in a conical flask. Then two drops of Tashiro or bromo cresol green indicator were added. The green color of the sample was developed. The resulting mixture was titrated against a standard $0.02 \mathrm{~N}$ sulfuric acid to a permanent pink color. The following equation was used in the calculation.

Alkalinity of unknown solution was determined by the equation:

$\mathrm{M}_{\text {acid }} \times \mathrm{V}_{\text {acid }}=\mathrm{M}_{\text {base }} \times \mathrm{V}_{\text {base }}$

\section{Chloride Ion ( $\left.\mathrm{Cl}^{-}\right)$Concentration}

$50 \mathrm{~mL}$ of the water sample was taken in a $250 \mathrm{~mL}$ conical flask and 3 drops of $\mathrm{K}_{2} \mathrm{Cr}_{2} \mathrm{O}_{7}$ as an indicator were added into the contents of the flask. The sample color becomes yellow. Then the contents in the conical flask were titrated against $0.1 \mathrm{~N}$ $\mathrm{AgNO}_{3}$ solution until the end point indicated by a permanent red color. Titration was repeated three times. The value of the average titer was recorded.

Chloride $\left(\frac{m}{l}\right)=\frac{\text { titre walue } X \text { Normality of Silver Nitrate } \times \text { Eq wt of } \mathrm{Cl} \times 1000}{\text { Volume of smple }}$

\section{Fluoride ion (F) concentration}

Palintest method: The sample water was filled to the $10 \mathrm{~mL}$ mark in a test tube. Crushed and dissolved one Fluoride No. 1 tablet of Zirconyl chloride, then crushed and dissolved one Eriochrome Cyanine R Fluoride No.2 tablet. Full colour development was allowed for five minutes. A standard solution was used to calibrate the photometer. A test tube containing sample solution was inserted in the photometer, and relavant programme was selected to measure the fluoride concentration in $\mathrm{mg} / \mathrm{L}$ [29]. 
SPSS (Statiscal Package for Social Sciences, version 25) was used to derive descriptive data.

\section{Results and Discussion}

The raw data collected from laboratory analysis was used to calculate the mean values of all the parameters. Tables are used to display the mean values. The data from the experiments were analyzed using the SPSS software [30]. Experiment data were graphed, and the study results were compared to WHO and PAK-EPA (Pakistan Environmental Protection Agency) guidelines. The permissible limits for many parameters are identical.

All the forty-three samples were colorless and odorless according to WHO and PAK-EPA instructions. Taste and $\mathrm{pH}$ values for all the analyzed samples are given in Table 2. Twenty-four samples out of forty-three samples were tasteless. The saline taste was observed in the water of Isa Khel city and Sheikh Abad. The bitter taste of water was observed in Kamar Mashani and its surrounding areas. The salt mines in the surrounding area of Sheikh Abad and Kamar Mashani may be responsible for the saline and bitter taste.

$\mathrm{pH}$ shows the amount of hydrogen ions $\left(\mathrm{H}^{+}\right)$concentration in a substance. Water with pH below 7.0 (0-6.9) is acidic, and water with a $\mathrm{pH}$ greater than 7.0 (7.1-14.0) is basic or alkaline. According to WHO and PAK-EPA, the minimum and maximum permissible $\mathrm{pH}$ ranges from 6.5 to 8.5 for potable water. Table 2 shows that the $\mathrm{pH}$ of water obtained from these forty-three areas varied from $\mathrm{pH} 7.0$ to 8.2 , which is within the minimum and maximum allowable $\mathrm{pH}$ range of $\mathrm{WHO}$ and PAK-EPA [31].
Table 2. Taste, $\mathrm{pH}$, electrical conductivity and $\mathrm{M}$. al kalinity.

\begin{tabular}{|c|c|c|c|c|}
\hline Sample ID & Taste & pH & $\begin{array}{c}\text { EC } \\
(\mu \mathrm{S} / \mathrm{cm})\end{array}$ & $\begin{array}{c}\text { M. } \\
\text { Alkalinity }\end{array}$ \\
\hline S.01 & Saline & $7.1 \pm 0.93$ & $5880 \pm 10.52$ & $494 \pm 31.93$ \\
\hline S.02 & Tasteless & $8.0 \pm 0.65$ & $1555 \pm 3.25$ & $294 \pm 6.23$ \\
\hline S.03 & Saline & $7.4 \pm 1.14$ & $7060 \pm 113.63$ & $566 \pm 8.14$ \\
\hline S.04 & Tasteless & $7.7 \pm 1.24$ & $1530 \pm 1.52$ & $150 \pm 3.56$ \\
\hline S.05 & Tasteless & $8.2 \pm 0.99$ & $347 \pm 2.51$ & $162 \pm 2.14$ \\
\hline S.06 & Tasteless & $7.8 \pm 1.54$ & $3920 \pm 1.32$ & $250 \pm 4.13$ \\
\hline S.07 & Tasteless & $7.5 \pm 1.59$ & $749 \pm 1.48$ & $300 \pm 5.24$ \\
\hline S.08 & Tasteless & $8.0 \pm 2.01$ & $1102 \pm 1.65$ & $382 \pm 5.26$ \\
\hline S.09 & Tasteless & $8.1 \pm 1.63$ & $1550 \pm 1.33$ & $300 \pm 6.58$ \\
\hline S.10 & Tasteless & $8.1 \pm 2.11$ & $1009 \pm 1.47$ & $320 \pm 8.23$ \\
\hline S.11 & Tasteless & $7.9 \pm 0.78$ & $1545 \pm 2.11$ & $136 \pm 2.15$ \\
\hline S.12 & Tasteless & $7.3 \pm 0.88$ & $1462 \pm 1.26$ & $260 \pm 3.12$ \\
\hline S.13 & Bitter & $7.5 \pm 1.12$ & $5040 \pm 81.73$ & $343 \pm 5.16$ \\
\hline S.14 & Bitter & $7.0 \pm 0.54$ & $3940 \pm 31.22$ & $297 \pm 4.59$ \\
\hline S. 15 & Bitter & $7.2 \pm 0.35$ & $4450 \pm 1.87$ & $179 \pm 2.13$ \\
\hline S.16 & Bitter & $7.4 \pm 0.86$ & $2500 \pm 150$ & $236 \pm 3.45$ \\
\hline S.17 & Tasteless & $7.5 \pm 0.64$ & $2560 \pm 155$ & $245 \pm 1.25$ \\
\hline S.18 & Tasteless & $8.0 \pm 1.13$ & $1505 \pm 1.23$ & $247 \pm 3.25$ \\
\hline S.19 & Tasteless & $7.5 \pm 1.45$ & $990 \pm 01.20$ & $362 \pm 7.25$ \\
\hline S. 20 & Tasteless & $8.0 \pm 0.60$ & $1480 \pm 1.11$ & $232 \pm 4.25$ \\
\hline S.21 & Bitter & $7.3 \pm 1.25$ & $2200 \pm 1.44$ & $241 \pm 3.15$ \\
\hline S.22 & Bitter & $7.5 \pm 1.10$ & $2820 \pm 1.21$ & $270 \pm 4.25$ \\
\hline S.23 & Bitter & $7.1 \pm 0.85$ & $3220 \pm 2.14$ & $209 \pm 2.15$ \\
\hline S. 24 & Bitter & $7.5 \pm 0.23$ & $2000 \pm 0.45$ & $294 \pm 1.69$ \\
\hline S.25 & Bitter & $8.0 \pm 1.15$ & $2160 \pm 1.77$ & $239 \pm 3.12$ \\
\hline S.26 & Bitter & $7.5 \pm 0.56$ & $2210 \pm 03.55$ & $410 \pm 7.12$ \\
\hline S. 27 & Bitter & $7.3 \pm 0.25$ & $1990 \pm 1.29$ & $284 \pm 4.15$ \\
\hline S. 28 & Bitter & $7.3 \pm 1.56$ & $24600 \pm 225.37$ & $282 \pm 5.23$ \\
\hline S.29 & Bitter & $7.8 \pm 0.69$ & $2820 \pm 14.45$ & $290 \pm 5.14$ \\
\hline S.30 & Bitter & $7.2 \pm 1.11$ & $2530 \pm 05.60$ & $264 \pm 5.16$ \\
\hline S. 31 & Bitter & $7.4 \pm 0.32$ & $24602 \pm 252.32$ & $384 \pm 6.75$ \\
\hline S.32 & Bitter & $7.3 \pm 1.23$ & $3430 \pm 1.25$ & $270 \pm 4.84$ \\
\hline S.33 & Bitter & $7.8 \pm 1.25$ & $1545 \pm 0.16$ & $270 \pm 5.12$ \\
\hline S.34 & Tasteless & $7.7 \pm 1.10$ & $1276 \pm 1.68$ & $310 \pm 4.12$ \\
\hline S.35 & Tasteless & $7.4 \pm 1.02$ & $1450 \pm 0.56$ & $310 \pm 4.16$ \\
\hline S.36 & Tasteless & $7.7 \pm 1.06$ & $992 \pm 1.41$ & $199 \pm 2.78$ \\
\hline S.37 & Tasteless & $7.7 \pm 0.69$ & $900 \pm 1.14$ & $299.8 \pm 5.25$ \\
\hline S.38 & Tasteless & $7.9 \pm 1.85$ & $1234 \pm 036$ & $450 \pm 6.25$ \\
\hline S.39 & Tasteless & $7.6 \pm 1.25$ & $657 \pm 0.12$ & $300 \pm 5.18$ \\
\hline S. 40 & Tasteless & $8.1 \pm 1.30$ & $2840 \pm 51.86$ & $398 \pm 6.45$ \\
\hline S.41 & Tasteless & $7.2 \pm 1.53$ & $2500 \pm 1.54$ & $254.8 \pm 5.45$ \\
\hline S.42 & Tasteless & $7.9 \pm 1.26$ & $300 \pm 0.58$ & $108 \pm 3.42$ \\
\hline S.43 & Tasteless & $7.6 \pm 0.56$ & $431 \pm 0.57$ & $140 \pm 2.14$ \\
\hline
\end{tabular}


Electrical Conductivity (EC), Total Dissolved Solids (TDS), Turbidity and Total Hardness

EC is an indicator of total dissolved salts. It determines whether water is capable of satisfying thirst or not. The conductivity of potable waters generally varies from 50 to $1500 \mu \mathrm{S} / \mathrm{cm}$. The conductivity of municipal wastewater may be near that of potable water. However, the industrial wastewater may have conductivities above 10,000 $\mu \mathrm{S} / \mathrm{cm}$. According to WHO and PAK-EPA standards, the EC value of the drinking water supply should not be exceeded $500 \mu \mathrm{S} / \mathrm{cm}$. Results data in Table 3 shows that the EC values of water obtained from these forty-three areas varied from 300 to $7460 \mu \mathrm{S} / \mathrm{cm}$. These data show that the EC value of only three samples out of forty-three samples was below the WHO and PAK-EPA maximum permissible limits. These results indicate that the water in Tehsil Isa Khel is highly ionized and has a high level of ionic activity due to high concentrations of dissolved salts. The high concentration of ions in water may be due to salt mines in the vicinity.

The TDS test is very important and determines the general quality of water. TDS are primarily made up of inorganic salts and small concentrations of organic matter in drinking water. Other contributory ions are carbonate, bicarbonate, chloride, sulphate, potassium, nitrate, magnesium and calcium. Rocks and soil are major sources of TDS in water. A minor source of TDS is pollution from urban runoff. The TDS values found in drinking water are very important. According to WHO and PAK-EPA standards, the maximum TDS permissible limit is $1000 \mathrm{ppm}$. The health risks are not as significant as TDS values are less than $1000 \mathrm{ppm}$.

From data in Table 3, water had TDS values varied from 192 to $4518 \mathrm{ppm}$, and it shows that TDS values of twenty-one samples out of forty-three samples are below the WHO and PAK-EPA maximum permissible limits (1000 ppm).

\section{Calcium and Magnesium Hardness}

Calcium is an alkaline earth element and fifth in abundance. It is found in the earth's crust. The most common compounds of calcium are limestone $\left(\mathrm{CaCO}_{3}\right)$, gypsum $\left(\mathrm{CaSO}_{4} .2 \mathrm{H}_{2} \mathrm{O}\right)$, fluorite $\left(\mathrm{CaF}_{2}\right)$, hypochlorite (ClOCa) and nitrate. It is an essential constituent of bones and teeth. According to WHO guidance, the maximum permissible limit of calcium in drinking water quality is $75 \mathrm{mg} / \mathrm{L}$ for internationally acceptable value and $200 \mathrm{mg} / \mathrm{L}$ as an excessive limit. Any specific disease has not been associated with calcium in drinking water. Its upper limit of $200 \mathrm{mg} / \mathrm{L}$ is in relation to hardness.

The laboratory results of calcium hardness in the study area are shown in Table 3 . The table shows that the calcium hardness of the various sampling points ranged from 28 to $1650 \mathrm{mg} / \mathrm{L}$, and twenty-two samples out of forty-three samples were within both WHO and PAK-EPA maximum acceptable standard $(200 \mathrm{mg} / \mathrm{L})$. The least level was observed in Gidran Wala $(28 \mathrm{mg} / \mathrm{L})$, and the highest level was observed in Sultan Khel, Moqeem colony $(1650 \mathrm{mg} / \mathrm{L})$.

Magnesium is a light silver-white metallic element. It is the eighth-most abundant element. It occurs in the earth's crust and is not found as a free element. Magnesium is used in alloys, flash-light photography, pyrotechnics and incendiary bombs. In medicine, magnesium is known as "milk of magnesia" as a hydroxide or "Epsom salts" as a sulfate. It is a nutritional element in plant and animal life. According to WHO, the international drinking water standard, the maximum allowable level is $150 \mathrm{mg} / \mathrm{L}$. The laboratory results in Table 3 shows that 
magnesium hardness was found in the range of $7 \mathrm{mg} / \mathrm{L}$ to $319 \mathrm{mg} / \mathrm{L}$. The data shows that magnesium hardness in twenty samples out of forty-three samples are below the maximum acceptable level set by WHO and PAK-EPA.

Table 3. Various physicochemical parameters of the analyzed samples.

\begin{tabular}{|c|c|c|c|c|c|c|c|}
\hline $\begin{array}{c}\text { Sample } \\
\text { ID }\end{array}$ & $\begin{array}{l}\text { TDS } \\
(\mathbf{p p m})\end{array}$ & $\begin{array}{c}\text { Turbidity } \\
\text { (NTU) }\end{array}$ & $\begin{array}{c}\text { TH } \\
(\mathrm{mg} / \mathrm{L})\end{array}$ & $\begin{array}{c}\text { Ca } \\
\text { Hardness } \\
(\mathrm{mg} / \mathrm{L})\end{array}$ & $\begin{array}{c}\text { Mg } \\
\text { Hardness } \\
\text { (mg/L) }\end{array}$ & $\begin{array}{c}\text { Chloride } \\
\text { (mg/L) }\end{array}$ & $\begin{array}{c}\text { Fluoride } \\
\text { (mg/L) }\end{array}$ \\
\hline S.01 & $3763 \pm 43.28$ & $5 \pm 0.28$ & $925 \pm 1.52$ & $285 \pm 11.23$ & $155 \pm 4.37$ & $1709 \pm 28.17$ & $4 . \pm 0.28$ \\
\hline S.02 & $995 \pm 27.36$ & $2 \pm 0.14$ & $188 \pm 0.98$ & $55 \pm 0.23$ & $321 \pm 14.23$ & $567 \pm 1.25$ & $5 . \pm 0.18$ \\
\hline S.03 & $4518 \pm 33.58$ & $5 \pm 0.31$ & $1120 \pm 2.52$ & $333 \pm 10.45$ & $191 \pm 1.52$ & $1808 \pm 25.23$ & $4.8 \pm 0.01$ \\
\hline S.04 & $979 \pm 13.46$ & $2 \pm 0.27$ & $256 \pm 1.0$ & $106 \pm 6.23$ & $36 \pm 0.23$ & $226 \pm 0.58$ & $3.2 \pm 0.01$ \\
\hline S.05 & $222 \pm 11.26$ & $0 \pm 0.01$ & $56 \pm 0.56$ & $28 \pm 0.04$ & $7 \pm 0.11$ & $14.2 \pm 0.04$ & $0.62 \pm 0.02$ \\
\hline S.06 & $2509 \pm 40.12$ & $4 \pm 0.14$ & $444 \pm 1.98$ & $178 \pm 0.32$ & $63 \pm 0.26$ & $510 \pm 11.12$ & $6.9 \pm 0.04$ \\
\hline S.07 & $479 \pm 17.23$ & $1 \pm 0.32$ & $280 \pm 1.66$ & $180 \pm 8.42$ & $24 \pm 0.07$ & $42.4 \pm 0.56$ & $1.5 \pm 0.05$ \\
\hline S.08 & $705 \pm 16.3$ & $2 \pm 0.02$ & $147 \pm 1.01$ & $43 \pm 0.08$ & $25 \pm 0.13$ & $70.9 \pm 0.84$ & $4.4 \pm 0.06$ \\
\hline S.09 & $992 \pm 21.53$ & $2 \pm 0.09$ & $190 \pm 0.53$ & $56 \pm 0.10$ & $32 \pm 0.09$ & $56.7 \pm 0.65$ & $5.5 \pm 0.09$ \\
\hline S.10 & $645 \pm 19.33$ & $1 \pm 0.13$ & $100 \pm 0.24$ & $32 \pm 0.21$ & $16 \pm 0.08$ & $63.8 \pm 0.98$ & $1.05 \pm 0.05$ \\
\hline S.11 & $989 \pm 23.12$ & $2 \pm 0.20$ & $450 \pm 9.21$ & $140 \pm 0.91$ & $75 \pm 0.14$ & $156 \pm 0.65$ & $4.1 \pm 0.01$ \\
\hline S.12 & $936 \pm 17.42$ & $2 \pm 0.15$ & $450 \pm 1.44$ & $184 \pm 0.43$ & $64 \pm 0.35$ & $56.7 \pm 0.87$ & $6.2 \pm 0.02$ \\
\hline S.13 & $3225 \pm 54.22$ & $5 \pm 0.32$ & $2983 \pm 4.53$ & $1650 \pm 27.58$ & $324 \pm 6.25$ & $70.9 \pm 6.11$ & $10 . \pm 0.12$ \\
\hline S. 14 & $2521 \pm 33.22$ & $4 \pm 0.04$ & $2205 \pm 2.47$ & $905 \pm 18.43$ & $315 \pm 13.22$ & $63.8 \pm 0.54$ & $8.7 \pm 0.10$ \\
\hline S.15 & $2848 \pm 31.47$ & $5 \pm 0.45$ & $2572 \pm 32.54$ & $1089 \pm 21.14$ & $360 \pm 0.46$ & $56.7 \pm 0.75$ & $9.5 \pm 0.05$ \\
\hline S.16 & $1600 \pm 27.42$ & $3 \pm 0.31$ & $1500 \pm 3.52$ & $525 \pm 0.34$ & $236 \pm 0.89$ & $42.5 \pm 1.24$ & $6.4 \pm 0.10$ \\
\hline S.17 & $1638 \pm 21.52$ & $3 \pm 0.17$ & $1325 \pm 15.45$ & $525 \pm 1.15$ & $194 \pm 1.10$ & $56.7 \pm 0.98$ & $6.4 \pm 0.05$ \\
\hline S.18 & $963 \pm 22.45$ & $2 \pm 0.08$ & $523 \pm 1.02$ & $220 \pm 1.24$ & $73 \pm 0.05$ & $35.4 \pm 0.12$ & $4.4 \pm 0.04$ \\
\hline S.19 & $634 \pm 18.54$ & $2 \pm 0.11$ & $303 \pm 1.01$ & $103 \pm 0.08$ & $49 \pm 0.21$ & $42.5 \pm 0.24$ & $4.4 \pm 0.01$ \\
\hline S. 20 & $947 \pm 33.14$ & $2 \pm 0.30$ & $705 \pm 22.65$ & $283 \pm 9.45$ & $103 \pm 0.75$ & $42.5 \pm 0.42$ & $3.9 \pm 0.03$ \\
\hline S. 21 & $1785 \pm 35.52$ & $3 \pm 0.12$ & $1590 \pm 26.11$ & $533 \pm 15.32$ & $256 \pm 15.66$ & $42.5 \pm 0.14$ & $7.0 \pm 0.03$ \\
\hline S. 22 & $1805 \pm 22.13$ & $3 \pm 0.52$ & $1620 \pm 1.66$ & $548 \pm 33.12$ & $260 \pm 21.56$ & $42.5 \pm 0.56$ & $8.5 \pm 0.07$ \\
\hline S.23 & $2060 \pm 31.58$ & $3 \pm 0.07$ & $1650 \pm 19.13$ & $526 \pm 22.12$ & $273 \pm 19.12$ & $113.5 \pm 0.54$ & $8.2 \pm 0.08$ \\
\hline S.24 & $1280 \pm 27.33$ & $2 \pm 0.11$ & $1000 \pm 2.14$ & $350 \pm 17.26$ & $158 \pm 1.23$ & $49.6 \pm 0.65$ & $6.3 \pm 0.04$ \\
\hline S. 25 & $1382 \pm 26.42$ & $2 \pm 0.32$ & $1033 \pm 54.22$ & $327 \pm 26.11$ & $171 \pm 0.58$ & $63.8 \pm 0.74$ & $6.8 \pm 0.05$ \\
\hline S.26 & $1414 \pm 47.25$ & $2 \pm 0.20$ & $794 \pm 25.37$ & $396 \pm 25.27$ & $96 \pm 0.47$ & $212.7 \pm 23.95$ & $7.4 \pm 0.09$ \\
\hline S.27 & $1273 \pm 22.33$ & $2 \pm 0.05$ & $744 \pm 23.78$ & $274 \pm 1.14$ & $114 \pm 0.98$ & $28.4 \pm 0.25$ & $6.0 \pm 0.01$ \\
\hline S. 28 & $1574 \pm 11.54$ & $3 \pm 0.18$ & $1316 \pm 33.25$ & $483 \pm 1.16$ & $202 \pm 0.54$ & $28.4 \pm 0.98$ & $7.4 \pm 0.04$ \\
\hline S. 29 & $1804 \pm 26.13$ & $3 \pm 0.12$ & $1090 \pm 26.85$ & $323 \pm 0.92$ & $186 \pm 24.95$ & $354.5 \pm 0.42$ & $8.9 \pm 0.04$ \\
\hline S. 30 & $1619 \pm 29.54$ & $3 \pm 0.16$ & $850 \pm 25.63$ & $285 \pm 0.65$ & $137 \pm 0.95$ & $326 \pm 14.25$ & $7.5 \pm 0.08$ \\
\hline S. 31 & $1574 \pm 21.35$ & $3 \pm 0.17$ & $740 \pm 9.56$ & $266 \pm 0.45$ & $115 \pm 0.52$ & $290.7 \pm 8.25$ & $6.1 \pm 0.10$ \\
\hline S.32 & $2195 \pm 35.25$ & $3 \pm 0.26$ & $800 \pm 26.53$ & $265 \pm 1.10$ & $130 \pm 0.36$ & $460 \pm 25.23$ & $7.1 \pm 0.04$ \\
\hline S.33 & $989 \pm 31.56$ & $2 \pm 0.04$ & $440 \pm 1.21$ & $184 \pm 0.69$ & $62 \pm 0.24$ & $106.4 \pm 0.14$ & $4.4 \pm 0.07$ \\
\hline S.34 & $816 \pm 26.14$ & $2 \pm 0.31$ & $266 \pm 1.55$ & $123 \pm 0.25$ & $35 \pm 0.16$ & $70.9 \pm 0.35$ & $3.6 \pm 0.35$ \\
\hline S.35 & $928 \pm 23.16$ & $2 \pm 0.20$ & $336 \pm 14.58$ & $150 \pm 0.09$ & $45 \pm 0.54$ & $120.5 \pm 0.98$ & $3.2 \pm 0.14$ \\
\hline S.36 & $635 \pm 17.25$ & $1 \pm 0.07$ & $211 \pm 0.33$ & $110 \pm 1.10$ & $24.5 \pm 0.24$ & $78 \pm 0.24$ & $5.3 \pm 0.34$ \\
\hline S.37 & $576 \pm 11.25$ & $1 \pm 0.00$ & $436 \pm 23.11$ & $206 \pm 0.16$ & $56 \pm 0.05$ & $42.5 \pm 0.35$ & $1.5 \pm 0.14$ \\
\hline S.38 & $790 \pm 23.12$ & $2 \pm 0.05$ & $130 \pm 1.11$ & $44 \pm 0.09$ & $20.9 \pm 0.24$ & $70.9 \pm 0.54$ & $1.7 \pm 0.24$ \\
\hline S.39 & $421 \pm 16.32$ & $1 \pm 0.07$ & $220 \pm 1.42$ & $124 \pm 0.08$ & $23 \pm 0.08$ & $28.4 \pm 0.14$ & $0.31 \pm 0.35$ \\
\hline S.40 & $1817 \pm 29.52$ & $5 \pm 0.32$ & $128 \pm 0.38$ & $96 \pm 0.98$ & $7.8 \pm 0.32$ & $567 \pm 0.87$ & $3.0 \pm 0.09$ \\
\hline S.41 & $1600 \pm 47.52$ & $4 \pm 0.36$ & $980 \pm 18.23$ & $406 \pm 0.92$ & $139 \pm 0.48$ & $248 \pm 0.98$ & $1.5 \pm 0.08$ \\
\hline S. 42 & $192 \pm 21.53$ & - & $132 \pm 2.41$ & $90 \pm 0.04$ & $10.2 \pm 0.65$ & $17.7 \pm 0.65$ & $0.61 \pm 0.11$ \\
\hline S.43 & $276 \pm 11.25$ & - & $172 \pm 0.85$ & $108 \pm 1.01$ & $15.5 \pm 0.54$ & $28.4 \pm 0.97$ & $0.62 \pm 0.12$ \\
\hline
\end{tabular}




\section{Chloride and Fluoride}

Chlorides are soluble in water and harmless at low levels, therefore, reducible by dilution. Its concentration at a higher level in water is an indication of pollution. High chloride level in water destroys structures and harms growing plants.

According to WHO and Pak-EPA standards, chloride concentration should not exceed $250 \mathrm{mg} / \mathrm{L}$ [32]. Chloride concentration in the study area ranged from 14.2 to 1808 $\mathrm{mg} / \mathrm{L}$, as shown in Table 3. In Isa Khel city and Sheikh Abad, water was saline due to high chloride concentration. The data shows that 36 samples have a lower chloride concentration than the maximum permissible limit value set by both WHO and PAK-EPA guidance levels. The lowest chloride ion level was found in Gidran Wala $(14.2 \mathrm{mg} / \mathrm{L})$, and the highest chloride level was found in Sheikh Abad and Isa Khel city (1808 mg/L and $1709 \mathrm{mg} / \mathrm{L}$, respectively).

Fluoride in tiny amounts is essential for human beings because it reduces dental caries. Its optimum level is $1 \mathrm{mg} / \mathrm{L}$, and above this level, it is very dangerous. Fluoride level above $1.5 \mathrm{mg} / \mathrm{L}$ is not permissible in drinking water [33]. In fact, the high concentration of fluoride leads to dental fluorosis and skeletal fluorosis. The more dangerous is the deformation of the skelton. In the study area, the fluoride level ranged from 0.61 to 10.6 $\mathrm{mg} / \mathrm{L}$, as shown in Table 3. The least fluoride level was observed in Kala Bagh $(0.61 \mathrm{mg} / \mathrm{L})$, and the highest concentration level was observed in Sultan Khel Moqeeem Colony $(10.6 \mathrm{mg} / \mathrm{L})$.

The data shows that fluoride concentration in eight out of forty-three samples was below the WHO and PAK-EPA maximum permissible limit. As a result, fluoride has a health effect on the community that uses the water. The source of fluoride in the analyzed water is due to the high content of minerals in the salt range of Punjab [11].

The above Table 4 shows correlation among the investigated parameters. Strong correlation exists among TDS, turbidity and chloride concentration; turbidity and $\mathrm{TH}$; $\mathrm{TH}$, calcium hardness and fluoride concentration; Ca-hardness and fluoride concentration. Negative correlation is shown between $\mathrm{Ca}$-hardness and fluoride concentration. While weak or mild correlation is present among TDS and Mg-hardness; turbidity and Mg-hardness; TH, Mg-hardness andchloride; $\mathrm{Ca}$-hardness and Mg-hardness; Mg-hardness, chloride and fluoride concentration; chloride and fluoride concentrations.

Table 4. Correlation table of the studies parameters.

\begin{tabular}{lccccccc}
\hline Parameters & $\begin{array}{c}\text { TDS } \\
(\mathbf{p p m})\end{array}$ & $\begin{array}{c}\text { Turbidity } \\
(\mathbf{N T U})\end{array}$ & $\begin{array}{c}\text { TH } \\
(\mathbf{m g} / \mathbf{L})\end{array}$ & $\begin{array}{c}\text { Ca Hardness } \\
(\mathbf{m g} / \mathbf{L})\end{array}$ & $\begin{array}{c}\text { Mg Hardness } \\
(\mathbf{m g} / \mathbf{L})\end{array}$ & $\begin{array}{c}\text { Chloride } \\
(\mathbf{m g} / \mathbf{L})\end{array}$ & $\begin{array}{c}\text { Fluoride } \\
(\mathbf{m g} / \mathbf{L})\end{array}$ \\
\hline TDS (ppm) & 1 & & & & & \\
Turbidity (NTU) & $\mathbf{0 . 9 0}$ & 1 & & & & \\
TH (mg/L) & 0.68 & $\mathbf{0 . 6 6}$ & 1 & & & \\
Ca Hardness (mg/L) & 0.60 & 0.61 & $\mathbf{0 . 9 6}$ & 1 & & \\
Mg Hardness (mg/L) & 0.05 & 0.06 & 0.05 & 0.05 & 1 & & \\
Chloride (mg/L) & $\mathbf{0 . 7 0}$ & 0.54 & 0.02 & -0.06 & 0.03 & 1 \\
Fluoride (mg/L) & 0.59 & 0.59 & $\mathbf{0 . 7 6}$ & $\mathbf{0 . 6 8}$ & 0.04 & 0.02 & 1 \\
\hline
\end{tabular}




\section{Conclusion}

A total of 43 selected representative water samples from different places in Tehsil Isa Khel were used to characterize and analyze for quality characteristics. In order to determine a safe and acceptable level of drinking water for consumers, the water quality indicators were compared to the WHO allowed limit, and the PAK-EPA suggested values. Overall, the $\mathrm{pH}$ of all the forty-three analyzed samples was within the permissible limit set by WHO and PAK-EPA. Only three samples are in the range for EC, twenty-two samples for calcium hardness, twenty samples for magnesium hardness, thirty-six samples for chloride concentration, and only eight samples are in the correct range set for the fluoride concentration.

\section{Acknowledgment}

The authors (Hizbullah Khan and Muhammad Sirajuddin) are thankful to Higher Education Commission (HEC) Pakistan for providing the financial support, project number 10669.

\section{Conflict of interest}

The authors declare no conflict of interest for the reported research work.

\section{References}

1. M. Mohsin, S. Safdar, F. Asghar and F. Jamal, Int. J. Human. Soc. Sci., 3 (2013) 114. https://d1wqtxts1xzle 7.cloudfront.net/53 $\underline{628036}$

2. M. Vidar, M. A. Mekouar, Water health and human rights, World Water Day WHO: World Health Organization, 2001.

https://www.tandfonline.com/doi/full/10. 1080
3. A. Benignos, I. Malina.: Published, (2012).

https://sswm.info/sites/default/files

4. S. Khan, M. Shahnaz, N. Jehan, S. Rehman, M. T. Shah and I. Din, J. Clean. Prod., 60 (2013) 93. https://doi.org/10.1016/j.jclepro.2012.02. $\underline{016}$

5. S. Muhammad, M. T. Shah and S. Khan, Microchem. J., 98 (2011) 334.

https://doi.org/10.1016/j.microc.2011.03. $\underline{003}$

6. L. Domènech and D. Saurí, J. Clean. Prod., 19 (2011) 598. https://doi.org/10.1016/j.jclepro.2010.11. 010;bT.

7. U. WHO, Joint Monitoring Programme for water supply and sanitation (JMP), (2012).

https://apps.who.int/iris/bitstream

8. A. Pruss-Ustun, C. F. Corvalán, Organization, W. H., Preventing disease through healthy environments: towards an estimate of the environmental burden of disease. World Health Organization. 2006.

http//www. apps.who.int

9. F. Brikke, and World Health Organization, (2000). Operation and maintenance of rural water supply and sanitation systems: A training package for managers and planners (No. WHO/SDE/WSH/00.2). World Health Organization.

https://apps.who.int/iris/bitstream/handle $/ 10665$

10. S. K. Karn, H. Harada, Water Sci. Technol., 46 (2002) 269. https://doi.org/10.2166/wst.2002.0749

11. U. N. D. o. P. Information, The millennium development goals report 2005. United Nations Publications. 2005.

https://journals.plos.org/plosmedicine/art icle 
12. D. Kemp, C. J. Bond, D. M. Franks, C. Cote, J. Clean. Prod., 18 (2010) 1553. https://doi.org/10.1016/j.jclepro.2010.06.008

13. P. Chilton, D. Jamieson, M. Abid, C. Milne, M. Ince and J. Aziz, Scooping study-draft final report. Loughborough, UK, Water Engineering Development Centre, Loughborough University \& London School of Hygiene and Tropical Medicines, (2001).

https://wedc-knowledge.lboro.ac.uk/

14. N. Yuzbasi, E. Sezgin, Z. Yildirim, M.

Yildirim, J. Food Qual., 32 (2009) 73.

https://doi.org/10.1111/j.17454557.2007.00167.x

15. A. Azizullah, M. N. K., Khattak, P. Richter and D.-P. Häder, Environ. Int., 37 (2011) 479.

https://doi.org/10.1016/j.envint.2010.10. $\underline{007}$

16. W. H. Organization, Arsenic in drinkingwater: Background document for development of WHO guidelines for drinking-water quality. World Health Organization: 2003.

https://apps.who.int/iris/bitstream/handle $/ 10665$

17. a. World Health Organization, 2008. Guidelines for drinking-water quality 3rd edition incorporating the first and second addenda. https://www.who.int/water_sanitation_h ealth/dwq/fulltext.pdf

b. A. Ilyas, T. Sarwar, Pak. J. Biol. Sci., 6 (2003) 86.

https://portal.research.lu.se/en/publicatio $\underline{\mathrm{ns}}$

18. R. A. Sial, M. F. Chaudhary, S. T. Abbas, M. I. Latif, A. G. Khan, Quality of effluents from Hattar industrial estate. J. Zhejiang Univ. Sci. B, 7 (12) (2006) 974.

https://link.springer.com/article/10.1631/ jzus.2006.B0974

19. T. A. Adesakin, A. T. Oyewale, U. Bayero, A. N. Mohammed, I. A. Aduwo, P. Z. Ahmed, N. D. Abubakar, I. B.
Barje, Heliyon, 6 (2020) e04773. https://doi.org/10.1016/j.heliyon.2020.e04773.

20. M. S. Islam, S. C. Mohanta, M. A. B. Siddique, M. Abdullah-Al-Mamun, N. Hossain and U. H. Bithi, Int. J. Eng. Sci., 7 (2018) 57.

https://theijes.com/papers/vol7issue 1/G0701015762.pdf

21. E. Borgonovo and E. Plischke, Eur. J. Oper. Res., $248 \quad$ (2016) 869. https://doi.org/10.1016/j.ejor.2015.06.032

22. W. Indrasari, E. Budi, , S. R. Alayya and R. Ramli, J. Phys. Conf. Ser. IOP Publishing: $1317 \quad$ (2019) 869. https://scholar.google.com/citations

23. A. F. Rusydi, , In IOP conference series: earth and environmental science. 118 (2018) 012019). IOP Publishing. https://iopscience.iop.org/article/10.1 088/1755-1315/118/1/012019/meta

24. H. Singh, B. Dunn, Electrical conductivity and $\mathrm{pH}$ guide for hydroponics. Oklahoma Cooperative Extension Service: (2016).

25. B. G. Kitchener, J. Wainwright and A. J. Parsons, Prog. Phys. Geogr. 41 (2017) 620.

https://doi.org/10.1177/0309133317726540

26. A. Pal, M. Mukherjee, P. Bagchi, A. Raha, Asian J. Pharm., 4 (2018) 203. doi: 10.31024/ajpp.2018.4.2.17.

27. C. E. Boyd, Total Hardness. In Water Quality, Springer: (2020) 205.

doi: 10.1007/978-3-030-23335-8_10

28. S. S. Nielsen, Water Hardness Testing by Complexometric Determination of Calcium. Food Analysis Laboratory Manual, Springer: (2017) 147.

29. D. A. N. Fernando, P. L. A. T. Cooray and S. S. L. W. Liyanage, Comparison of Colorimetric and Ion Chromatographic methods for Aqueous Fluoride Analysis. Proceedings of International Forestry and Environment Symposium, 23 (2018).

https://doi.org/10.31357/fesympo.v23i0.3771. 
30. F. J. Holler and S. R., Crouch, Applications of Microsoft Excel in Analytical Chemistry. Cengage Learning, $2^{\text {nd }} \operatorname{Ed}$ (2013).

https://www.amazon.com/ApplicationsMicrosoft-Excel-AnalyticalChemistry/dp/128508795X

31. D. Q. Ng and Y. P. Lin, Environ. Chem, 13 (2015) 602.

https://doi.org/10.1071/EN15156
32. B. Murtaza, F.Naeem, M. Shahid, G. Abbas, N. S. Shah, M. Amjad, H. F. Bakhat, M. Imran, N. K. Niazi and G. Murtaza, Environ. Sci. Pollut. Res., 26 (2019) 362 .

https://doi.org/10.1007/s11356-018-3605-7

33. I. Hussain, M. Arif and J. Hussain, Environ. Monit. Assess., 184 (2012) 5151.

https://doi.org/10.1007/s10661-011-2329-7. 